\title{
Borsa Birleşmelerinin Endeksler Üzerine Etkisi: Nasdaq Omx Örneği (The Impact of Stock Market Integration on Indices: Nasdaq Omx Case)
}

\section{Turan KOCABIYIK (D) a Türker TEKER (D) b}

a Süleyman Demirel Üniversitesi, Bankacılık ve Finans Bölümü, Isparta, Türkiye. turankocabiyik@sdu.edu.tr

b Süleyman Demirel Üniversitesi, Bankacılık ve Finans Bölümü, Isparta, Türkiye. turkerteker@sdu.edu.tr

\begin{tabular}{|c|c|}
\hline MAKALE BİLGİSİ & ÖZET \\
\hline Anahtar Kelimeler: & $\begin{array}{l}\text { Amaç - Bu çalışmanın amacı, Nasdaq OMX bünyesinde yer alan Kuzey Avrupa borsalarının ana } \\
\text { endeksleri arasındaki ilişkiyi keşfetmektir. Aynı çatı altında faaliyet gösteren farklı ülke borsaları } \\
\text { rrasındaki ilişki yatırımcılara portföy riskini kontrol edebilme açısından yol gösterecektir. }\end{array}$ \\
\hline $\begin{array}{l}\text { Gönderilme Tarihi } 22 \text { Ocak } \\
2020 \\
\text { Revizyon Tarihi } 17 \text { Mayıs } 2020\end{array}$ & $\begin{array}{l}\text { Yöntem - Bu amaçla, çalışmada veri seti olarak 05.11.2013-10.10.2018 tarihleri arasındaki günlük } \\
\text { piyasa kapanış verileri kullanılmıştır. Nasdaq grubuna bağlı olarak faaliyet gösteren borsalara ait } 8 \\
\text { ayrı ülkenin ana endeksleri, NordicALL40 ve Baltic10 grup endeksleri analizde yer alan } \\
\text { endekslerdir. Çalışmada öncelikle serilerin yapısal kırılmalarını dikkate alan Lee Strazicich birim } \\
\text { kök testi uygulanmıştır. Ardından optimal gecikme uzunluğu belirlenmiştir ve daha sonra } \\
\text { değişkenler arasında herhangi bir nedensellik olup olmadığını ve ilişkinin yönünü belirlemek için } \\
\text { Toda-Yamamoto Modeli uygulanmıştır. }\end{array}$ \\
\hline layis 2020 & $\begin{array}{l}\text { Bulgular-Sonuçta, Baltic10 endeksinden NordicALL } 40 \text { endeksine doğru bir nedensellik ilişkisi söz } \\
\text { konusudur. Ayrıca Oslo20 endeksi hem NordicALL40 hem de Baltic10 endekslerinden } \\
\text { etkilenmektedir. }\end{array}$ \\
\hline $\begin{array}{l}\text { Makale Kategorısı: } \\
\text { Araştırma Makalesi }\end{array}$ & $\begin{array}{l}\text { Tartışma - Aynı coğrafyada yer alan borsaların birbirleriyle etkileşim içinde olması bu çalışmanın } \\
\text { bulgularından biridir. Benzer durumdaki diğer borsalar açısından da bu durumun mevcut olup } \\
\text { olmadığı yapılacak yeni araştırmalarla ortaya konabilir. }\end{array}$ \\
\hline ARTIC & ABSTRACT \\
\hline Keywords: & \multirow{6}{*}{$\begin{array}{l}\text { Purpose - The aim of this study is to explore the relationship between the main indices of Northern } \\
\text { European stock exchanges within Nasdaq OMX. The relationship between the stock exchanges of } \\
\text { different countries operating under the same roof will guide investors to control portfolio risk. } \\
\text { Design/methodology/approach - For this purpose, daily market closing data between 05.11.2013- } \\
10.10 .2018 \text { was used as data set in the study. The main indices of the } 8 \text { different countries, } \\
\text { NordicALL } 40 \text { and Baltic10 group indices belonging to the Nasdaq group are listed in the analysis } \\
\text { In the study, Lee Strazicich unit root test, which takes into account the structural breaks of the series, } \\
\text { was applied. The optimal lag length was then determined and then the Toda-Yamamoto Model was } \\
\text { applied to determine if there was any causality between the variables and the direction of the } \\
\text { relationship. }\end{array}$} \\
\hline $\begin{array}{l}\text { Nasdaq } \\
\text { Toda-Yamar }\end{array}$ & \\
\hline International Stock Exchanges & \\
\hline Received 22 January 2020 & \\
\hline Revised 17 May 2020 & \\
\hline Accepted 22 May 2020 & \\
\hline & $\begin{array}{l}\text { Findings - As a result, there is a causal relationship from the Baltic10 index to the NordicALL40 } \\
\text { index. The Oslo20 index is also influenced by both NordicALL40 and Baltic10 indices. }\end{array}$ \\
\hline Research Article & $\begin{array}{l}\text { Discussion - Located in the same region of the stock market in fact interact with each other, it was } \\
\text { one of the findings of this study. Whether this is the case for other stock exchanges in a similar } \\
\text { situation can be revealed with new researches to be conducted. }\end{array}$ \\
\hline
\end{tabular}

\section{GİRİS}

Nasdaq, (National Association of Securities Dealers Automated Quotations) resmi bir düzenleyicisi olmayan tezgâh üstü piyasalarda (OTC) alınıp satılan menkul değerlerin alım-satım fiyatlarının belirlendiği özel borsa olup Amerika Birleşik Devletleri'nin New York şehrinde yer almaktadır. Dünya'nın teknoloji borsası olarak da bilinmektedir (Vikipedia, 2018). Borsa, Amerika Birleşik Devletleri dışında birçok ülke borsasını satın almış olup bu borsalar, Nasdaq OMX çatısı altında faaliyetini sürdürmektedir. OMX AB ise 1984 yılında OM HEX $\mathrm{AB}$ ismiyle kurulan, 2004 Ağustos'ta adını OMX AB olarak değiştirmiş, Kuzey Avrupa ve Baltic borsalarını işleten, hisse senedi alışverişi, türev ürünler ticareti, takas saklama işlemleri yapan Stockholm merkezli bir şirkettir. 2008 yılında Nasdaq tarafından satın alınmış ve Nasdaq'ın bir yan kuruluşu olarak faaliyetlerine

\section{Suggested Citation}

Kocabıyık, T., Teker, T. (2020). Borsa Birleşmelerinin Endeksler Üzerine Etkisi: Nasdaq Omx Örneği İşletme Araştırmaları Dergisi, 12 (2), 1459-1474. 
devam etmektedir (Bloomberg, 2018). Nasdaq çatısı altında Amerika Birleşik Devletlerinde faaliyet gösteren Nasdaq Stock Exchange'in yanı sıra Nasdaq OMX Nordic çatısı altında Kopenhag, Stockholm, Helsinki ve İzlanda borsaları faaliyet göstermekte iken Nasdaq OMX Baltic ise Tallin, Riga ve Vilnius borsalarını bünyesinde barındırmaktadır. Ayrıca Oslo borsası da bu iki endeksten bağımsız olarak Nasdaq OMX Çatısı altında faaliyetlerine devam etmektedir (Nasdaq, 2018). Bu çalışma, yukarıda belirtildiği şekilde tek bir şirket çatısı altında toplanmış olan farklı ülkelere ait borsaların sergiledikleri performansların seyrini incelemeyi ve analiz etmeyi amaçlamaktadır.

Uluslararası borsa endeksleri arasındaki etkileşimi konu alan araştırmalar üzerine literatür değerlendirmesi yapıldığında, 1980'li yıllarda başlayan çalışmalarda ilk olarak korelasyon testleri kullanılmıştır daha sonra yapılan çalışmalarda ise daha yeni testlere yer verilmiştir. Johansen eşbütünleşme testi, hata düzeltme modeli, Granger nedensellik analizi, varyans ayrıştırma testleri ve etki-tepki analizleri bunlardan bazılarıdır. Literatürde çalışmaların büyük kısmı Amerika borsaları üzerine yapılmıştır. Ayrıca Birleşik Krallık, Hindistan, Yunanistan, Malezya ve diğer ülkeler üzerine yapılan çalışmalara da rastlanmıştır. Bazı çalışmalar çeşitli yönleriyle öne çıkmaktadır. Kazi, 57 yıllık veri ile en uzun dönemi kapsayan çalışma, Mukhopadhyay 46 ülke ile en çok değişkeni kapsayan çalışma ve Alam ve Hasan ise tek hisse senedi ile ekonomik gelişmişlik ve borsa büyüklüğü nedenselliğini araştıran çalışma özelliğini taşımaktadır (Sharma ve Seth, 2012). Hamao vd. (1990), Chan vd. (1997), Jeon ve Chiang (1991), Bekaert ve Campbell (1995) ve Choudhry (1996), yaptıkları araştırmalarda gelişmiş ülke borsalarını incelemişlerdir. Chittedi (2009), Gözbaşı (2010), Akel (2015), Mohanasundaram ve Karthikeyan (2015), Kılıç ve Dilber (2017) ve Öner (2018) ise çalışmalarında BRIC ülkeleri, Kırılgan Beşli ve gelişmekte olan ülkeler üzerine yoğunlaşmışlardır. Kimi çalışmalarda ise değişkenler belli bir coğrafi bölgeye odaklanmıştır. Choudhry vd. (2007), Chan vd. (1997) ve Çelik ve Boztosun (2010) çalışmalarında Asya-Pasifik ülke borsalarını, Tweneboah vd. (2019) ve Boujir ve Lahrech (2008) ise Afrika borsalarını araştırmışlardır. Gilmore vd. (2008), Worthington ve Higgs (2007), Angelovska (2017), Pietrzak vd. (2017), Verma ve Joseph (2019) ise Avrupa borsaları arasındaki etkileşimleri incelemişlerdir. Sriram (2017), Kalhoro vd. (2019) ve Wu vd. (2020) çalışmalarında ülke borsalarının karşılıklı etkileşiminde makroekonomik değişkenleri araştırmaya dahil ederken Iqbal vd. (2011), Bulut ve Özdemir (2012), Yıldız ve Aksoy (2014) ve Alvi vd. (2015) yerel borsa ile gelişmiş ülke karşılaştırması yapmışlardır.

Borsalar arası ilişkiyi inceleyen birçok çalışmaya literatürde rastlanmasına rağmen, Nasdaq OMX grubunu inceleyen araştırmaya rastlanmamıştır. $\mathrm{Bu}$ nedenle çalışmanın farklı bir noktaya temas ettiği düşünülmektedir.

Çalışmadan elde edilen sonuçların bireysel ve kurumsal yatırımcılar açısından yol gösterici olabileceği düşünülmektedir. Aynı şirket bünyesinde faaliyet gösteren borsaların, aynı coğrafyada yer alan borsaların ve endekslerin bağımsız hareket edebilme yetisinin bulunup bulunmadığı, birbirlerini etkileme güçleri bu çalışmanın irdelediği hususlardan biridir. Borsalar arasında eş yönlü ilişki bulunduğunda, yatırımcılar portföyün çeşitlendirmesinde bu borsaları kullanamayacaktır. Borsalar arasında ilişki yoksa bu durumda yatırımcılar portföy çeşitlendirmede tek çatı altında toplansalar da bu borsalardan yatırım araçları seçebilirler. Ayrıca ileride birleşmeye gitmeyi düşünen borsalar için yol gösterici olacağı düşünülmektedir.

Nedensellik analizleri değişkenlerin birbirlerini etkileme gücü ve uzun dönem ilişkileri ile ilgili olarak sıkça başvurulan yöntemlerdir. Borsaların ya da aynı borsa içerisinde yer alan farklı endekslerin birbirleri ile olan ilişkilerini ortaya koyma açısından da uygulanabilecek bir yöntem olarak görülmektedir. Nitekim literatürde borsalar arası ilişkileri inceleyen birçok çalışma bulunmaktadır. Bu çalışmada kırılmaları dikkate alan Lee Strazicich birim kök testlerinden ardından da yeni nesil kabul edilebilecek Toda-Yamamoto nedensellik analizlerinden yararlanılmıştır.

Bu çalışmada ilk olarak borsa birleşmeleri ile ilgili genel bilgilere yer verilmiştir. Ardından ikinci bölümde, benzer çalışmalarla ilgili bilgilerin yer aldığı literatür taraması bölümü oluşturulmuştur. Üçüncü bölümde çalışmanın veri seti tanımlanarak ardından ekonometrik analizler yapılmaktadır. Çalışmanın son bölümünde elde edilen bulgular değerlendirilmektedir.

\section{BORSA BİRLEŞMELERI}

Borsalar, şirketleşme süreciyle birlikte, rekabet gücünü artırabilmek adına satın alma, birleşme faaliyetlerinde bulunmaya başlamış ya da stratejik ortaklıklara önem vermeye başlamışlardır. Kendi ülkelerinde faaliyetlerini 
sürdüren, işlem öncesi ve sonrası hizmetler sunan firmalar öncelikli olarak tercih edilmişlerdir. Bu amaçla borsalar, takas ve mutabakat kurumları, veri dağıtım şirketleri, teknolojik altyapı sağlayıcı kurumlar gibi kendi operasyonlarına katkı sağlayabilecek kurumları satın alma eğilimine girmişlerdir. Ardından, hem kendi bölgelerinde yer alan hem de farklı ülkelerde faaliyet gösteren borsaları satın almayı ya da o borsalarla birleşerek rekabet yönünden avantajlı duruma gelmeyi amaçlamışlardır. Bu amaca yönelik olarak çeşitli menkul kıymet, para, emtia, enerji borsalarını, hatta alternatif işlem sistemlerini satın alarak gruplarına dahil etmiş, tek bir çatı altında örgütlenmeye başlamışlardır. Borsa büyümeleri aynı ülke borsalarını satın almak ya da bu borsalarla birleşmek ile kalmamış, komşu ülkelerin borsalarının satın alınması ve devamında okyanus aşırı borsalarla stratejik ortaklıklar kurma faaliyetleriyle devam etmiştir. Rekabetin artarak devam ettiği bu dönemde borsa birleşmelerine ek olarak birbirlerinden pay satın alma ya da işbirliği anlaşmaları yapma şeklinde faaliyetler de hız kazanmıştır. Tüm bunların sonucunda dünyada belli başlı borsa grupları oluşmuş, rekabet açısından bir yoğunlaşma meydana gelmiştir (Türkiye Sermaye Piyasaları Birliği, 2011, s.86).

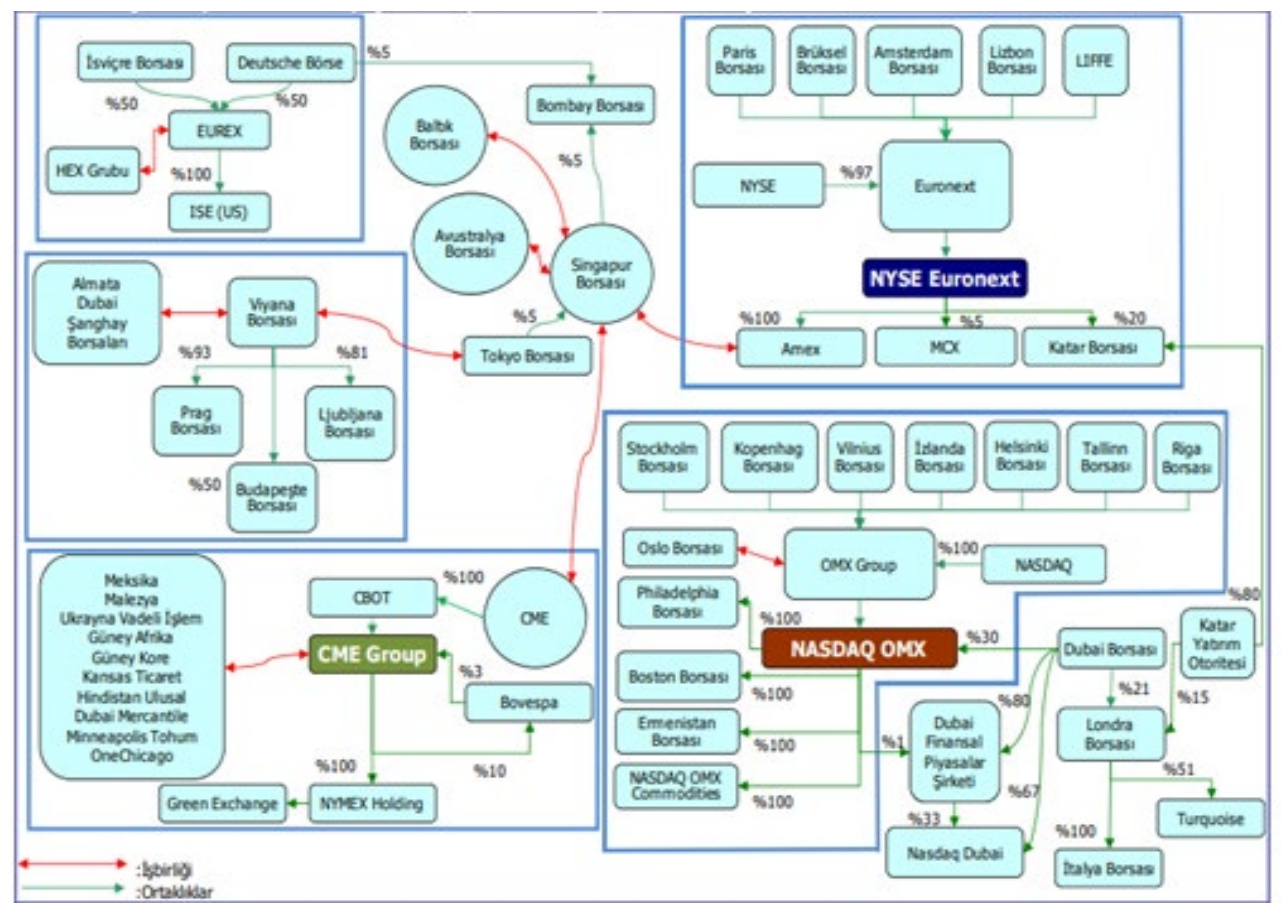

Grafik 1. Borsa Birleşmeleri, Satın Almalar, İşbirlikleri, Ortaklıklar

Kaynak: TSPAKB Aktaran: Türkiye Sermaye Piyasaları Birliği (2011)

Şekil 1'de, Dünya borsalarının ortaklık yapısı, birleşik olarak faaliyet gösteren borsalar ve borsalar arası işbirlikleriyle ilgili bilgi verilmektedir. Sermaye hareketlerindeki uluslararasılaşma ile doğru orantılı biçimde dünya borsalarında da birleşmeler ve işbirlikleri rahatlıkla görülmektedir.

\section{LITERATÜR TARAMASI}

Konuyla ilgili literatür incelendiğinde, Nasdaq OMX Çatısı altındaki borsaların birbirleri arasındaki etkileşimi ölçen herhangi bir çalışmaya rastlanmamıştır. Ancak, yöntem ve araştırma alanı göz önünde bulundurularak borsalar arasındaki eşbütünleşme ilişkisini ölçen çalışmalara literatür taramasında yer verilmiştir.

Chan vd. (1997), 1961-1992 yılları arasındaki aylık verilerden yararlanarak, Avustralya, Belçika, Kanada, Danimarka, Finlandiya, Fransa, Almanya, Hindistan, İtalya, Japonya, Hollanda, Norveç, Pakistan, İspanya, İsveç, İsviçre, Birleşik Krallık ve Amerika Birleşik Devletleri Borsaları arasındaki ilişkiyi incelemişlerdir. Ülkeler 7 ayrı gruba ayrılarak gruplardaki ülkeler arası eşbütünleşme ilişkisi olup olmadığı incelenmiştir. Çalışmanın bulgularına göre;

- 1961-1992 döneminde Asya Grubu olarak kabul edilen Japonya, Hindistan, Pakistan ve Avustralya arasinda,

- 1970-1979 ve 1980-1987 döneminde "Four Big European Community" grubu olarak adlandırılan, Birleşik Krallık, Almanya, Fransa ve İtalya arasında, 
- 1980-1987 döneminde “European Financial Centers" olarak kabul edilen, Birleşik Krallık, Almanya, Fransa, İsviçre ve Belçika arasında eşbütünleşme ilişkisi tespit edilmiştir.

Worthington ve Higgs (2007), Avustralya, Belçika, Danimarka, Fransa, Almanya, Yunanistan, İrlanda, İtalya, Hollanda, İspanya ve İngiltere olmak üzere 11 pazara ait hisse senetlerinin günlük fiyatlarını kullanarak bu ülkelerin borsaları arasındaki ilişkiyi incelemişlerdir. Bulgular, adı geçen borsalar arasında uzun dönem eşbütünleşme analizinin varlığını ortaya koymaktadır.

Choudhry vd. (2007), 1997-1998 Asya krizi döneminde Uzak Doğu Asya borsaları arasındaki uzun dönemli ilişkiyi araştırmıştır. Johansen eşbütünleşme analizi ve nedensellik testlerinin kullanıldığı çalışmanın bulguları kriz öncesi, kriz esnasında ve kriz sonrasında borsalar arasında uzun dönemli ilişkinin varlığını ortaya koymaktadır. En önemli ilişki ise kriz döneminde tespit edilmiştir.

Gilmore vd. (2008), Temmuz 1995-Şubat 2005 arası verilerden yararlanarak Çek Cumhuriyeti, Macaristan, Polonya, Almanya ve Birleşik Krallık borsaları arasındaki uzun ve kısa vadeli ilişkiyi incelemiştir. Yöntem olarak Johansen Eşbütünleşme analizinin kullanıldığı analiz sonucunda borsalar arası eşbütünleşme varlığ1 tespit edilememiştir.

BRIC ülkeleri olan Brezilya, Rusya, Hindistan ve Çin ile gelişmiş ülkeler kategorisindeki Amerika Birleşik Devletleri, Birleşik Krallık ve Japonya borsaları arasındaki ilişkinin incelendiği çalışmada, Granger nedensellik testi, Johansen eşbütünleşme testi ve Vektör Hata Düzeltme Modeli kullanılmıştır. Araştırmada Ocak 1998-A ğustos 2009 dönemine ait günlük veriler kullanılmıştır. Sonuç olarak, ABD ve Japonya borsalarının Hindistan borsasını etkilediği, aynı zamanda Hindistan borsasının da Brezilya ve Rusya'nın Granger nedeni olduğu ortaya konmuştur. Hindistan borsası ile diğer ülke borsaları arasında anlamlı bir ilişkiye rastlanmamıştır (Chittedi, 2009).

Gözbaşı (2010), Türkiye ile gelişmekte olan ülkeler arasında yer alan Brezilya, Arjantin, Meksika, Hindistan, Malezya, Macaristan ve Mısır borsaları arasındaki etkileşimi incelemeyi amaçladığı çalışmasında Aralık 1995Aralık 2008 arasındaki haftalık verilerden yararlanmıştır. Çalışmanın sonuçlarına göre Türkiye ile Brezilya Hindistan ve Mısır borsaları arasında uzun dönemli ilişkinin mevcut olduğunu göstermektedir.

Çelik ve Boztosun (2010), Türkiye ve Asya ülkelerinin hisse senedi piyasalarında yer alan endeksler arasındaki uzun dönemli ilişkiyi incelemişlerdir. Araştırmada Türkiye (Borsa İstanbul), Avustralya (All Ordinaries), Çin (Shanghai Composite), Hong Kong (Hang Seng), Hindistan (BSE 30), Endonezya (Jakarta Composite), Malezya (KLSE Composite), Japonya (Nikkei 225), Kore (Seoul Composite), Tayvan (Taiwan Weighted), Singapur (Straits Times) endeksleri yer almıştır. Araştırma sonunda elde edilen sonuçlar, Japonya, Çin ve Tayvan dışındaki Asya ülkeleri ile Borsa İstanbul arasında kuvvetli bir ilişki olduğunu göstermiştir. Eşbütünleşme testi sonuçlarına göre Borsa İstanbul ile Tayvan, Kore, Singapur ve Malezya borsaları uzun dönemde anlamlı bir ilişki tespit edilmiştir.

Iqbal A., Khalid N., ve Rafiq S. (2011), Ocak 2003-Aralık 2009 dönemini kapsayan günlük verileri kullanarak ABD hisse senedi piyasası ile Pakistan ve Hindistan piyasaları arasındaki ilişkiyi incelemektedir. Johansen eşbütünleşme testi aracıllğ̆ıla uzun dönem ilişki incelenmiş ve 3 borsa arasında uzun dönemli anlamlı bir ilişki tespit edilememiştir. Ancak yapılan Granger nedensellik testi sonuçları incelendiğinde New York borsasından Bombay ve Karaçi borsalarına doğru tek yönlü nedensellik ilişkisinin varlı̆̆ tespit edilmiştir.

Bulut ve Özdemir (2012), İstanbul Menkul Kıymetler Piyasası ile Dow Jones Industrial Endeksi arasındaki ilişkiyi ölçmek amacıyla 2001-2010 yılları arasındaki haftalık kapanış verilerini kullanarak gerçekleştirdikleri çalışmalarında Granger nedensellik analizi ve eşbütünleşme analizini kullanmışlardır. Araştırmanın sonuçları uzun dönemde 2 endeksin birlikte hareket ettiğini, kısa dönemde de Dow Jones Endeksinin İstanbul Menkul Kıymetler Borsası'nı etkilediğini ortaya koymuştur.

Yıldız ve Aksoy (2014), Morgan Stanley gelişmekte olan ülkeler piyasa endeksi ile Borsa İstanbul arasındaki olası eşbütünleşmenin varlığı ve şiddetini belirlemek amacıyla yapmış oldukları çalışmada endeksler arasında uzun dönemli eşbütünleşme ilişkisinin varlığını ortaya koymuşlardır. Kısa dönemde ise, hata düzeltme modeli uygulamışlar ve 16 dönem sonra endekslerin dengeye geldiğini ifade etmişlerdir.

Akel (2015), Morgan Stanley tarafından Ağustos 2013 tarihli araştırma raporunda 'Kırılgan Beşli' olarak ilan ettiği Türkiye, Brezilya, Endonezya, Güney Afrika ve Hindistan borsalarının haftalık kapanış verilerini 
kullanarak, 2000-2013 arası veriler ile bir çalışma yürütmüştür. Çalışmada yöntem olarak Johansen eşbütünleşme analizi ve Granger nedensellik testini kullanmıştır. Akel'in yaptığı çalışmaya göre adı geçen 5 ülkenin borsaları arasında hem uzun dönem hem de kısa dönemde anlamlı ilişki ve nedensellik bağı tespit edilmiştir.

Mohanasundaram ve Karthikeyan (2015), çalışmalarında Güney Afrika, Hindistan ve ABD borsaları arasındaki ilişkiyi kısa ve uzun dönemli olarak incelemişlerdir. Veri setini oluşturulurken Nisan 2004- Mart 2014 arasındaki 10 yıllık sürece ait aylık veriler tercih edilmiş ve JALSH (Güney Afrika), NIFTY (Hindistan) and NASDAQ (ABD) endeksleri ele alınmıştır. Endeksler arası korelasyonun yüksek olduğu tespit edilmiştir. Granger nedensellik testi sonucuna göre Güney Afrika borsası Hindistan borsasının Granger nedeni iken diğer ikilemelerde anlamlı bir ilişki tespit edilememiştir.

Alvi vd. (2015) Pakistan borsası ile gelişmiş ülkelerin borsaları arasındaki ilişkiyi incelemişlerdir. Araştırmada Pakistan'ın yanı sıra, Amerika Birleşik Devletleri, İngiltere, Kanada, Avustralya, Almanya, Japonya, Fransa ve Hollanda borsalarına yer verilmiştir. Çalışma 1 Temmuz 2007- Haziran 2014 dönemini kapsamıştır. Bulgular, Pakistan borsası ile gelişmiş ülke borsalarının birlikte bir hareket içinde olmadıklarını ortaya koymuştur.

Kılıç ve Dilber (2017), Türkiye ile BRICS ülkeleri arasındaki finansal ilişkiyi incelemişlerdir. Yöntem olarak kantil regresyon analizi belirlenmiş olup Borsa İstanbul ve Brezilya, Rusya, Hindistan, Çin ve Güney Afrika borsalarının getiri serileri kullanılmıştır. Veri seti 18.02.2013-17.02.2017 dönemindeki günlük verilerden oluşmaktadır. Çalışmanın bulgularına göre, bu ülkelerin borsaları ile Borsa İstanbul arasındaki birlikte hareket kabiliyeti çok yüksektir. Ayrıca korelasyon analizi sonuçlarına dayanılarak, bu borsalara aynı dönemde yatırım yapmanın risk taşıdığ 1 yorumu yapılabilmektedir.

Sriram (2017), döviz kurları, borsalar ve emtia piyasası arasındaki nedensellik ilişkisini Granger nedensellik testi ile ölçmeyi amaçlamaktadır. Çalışmada Hindistan piyasasına ait 2005-2014 yıllarını kapsayan veriler kullanılmıştır. Yapılan analizler, emtia piyasaları ile döviz kurları arasında karşılıklı nedensellik bağı olduğunu, ayrıca emtia piyasasından borsaya doğru tek yönlü Granger nedensellik ilişkisi tespit edildiğini göstermektedir. Döviz kuru ile emtia piyasaları arasındaki ilişki pozitif yönlü iken, emtia ile borsa arasındaki ilişki ise negatif yönlüdür.

Angelovska (2017), iki Balkan borsası olan Makedonya ve Hırvatistan borsaları arasındaki uzun dönemli ve kısa dönemli ilişkiyi analiz etmeyi amaçladığı çalışmasında, Johansen eşbütünleşme analizi ve Granger nedensellik analizi metotlarını kullanmıştır. Veri seti, 3 Ocak 2005-31 Mart 2017 aralığından oluşturulmuştur. Bulgular, iki borsa arası eşbütünleşme ilişkisi olduğunu, aynı zamanda birbirlerinin Granger nedeni olduklarını göstermektedir. Araştırmacı, bu nedenle çeşitlendirme amaçlanan portföylerde bu iki borsaya aynı anda yer verilmemesi gerektiğini ifade etmektedir.

Pietrzak vd. (2017), Orta Avrupa borsalarının birbirleriyle olan ilişkilerini incelemeyi amaçladıkları çalışmada 1997-2015 arası verilerden yararlanmışlardır. Çalışmada Avusturya, Çek Cumhuriyeti, Polonya, Macaristan ve Almanya borsaları analiz edilmiştir. Bulgular, adı geçen ülkeler arasında karşılıklı bağımlılık ilişkisi olduğunu ortaya koymaktadır.

Öner (2018) çalışmasında Standard and Poors tarafından kırılgan beşli olarak tanımlanan Türkiye, Pakistan, Katar, Mısır ve Arjantin Borsaları arasındaki entegrasyonu incelemek amaciyla 2009-2018 arası verilerden yararlanarak Granger nedensellik analizine başvurmuştur. Çalışmanın bulguları, Türkiye BİST 100 endeksi ve Arjantin Merval endeksinden Katar QE endeksine; Türkiye BİST 100 endeksi ve Arjantin Merval endeksinden Mısır Hermes endeksine; Türkiye BIST 100 endeksinden Pakistan KSE 100 endeksine doğru nedensellik ilişkisini ortaya koymuştur. Ayrıca, Arjantin Merval endeksinden Türkiye BİST 100 endeksine doğru tek yönlü Granger nedensellik ilişkisi tespit edildiğini göstermektedir.

Tweneboah vd. 2019 yılında gerçekleştirdikleri çalışmalarında Afrika'nın önemli büyüklükteki borsaları arasındaki eşbütünleşmeyi incelemişlerdir. Çalışmada 2011-2017 yılları arasında günlük ve haftalık veriler kullanılarak yedi Afrika borsası arasındaki ortak hareket ve karşılıklı bağımlılık yapısını araştırmak için dalgacıklar çoklu korelasyon ve dalgacıklar çapraz korelasyon teknikleri kullanılmıştır. Sonuçlar borsalar arasında bağlantılar olduğunu göstermektedir ve bu bağlar uzun vadelidir. Ayrıca, Gana Borsası diğer pazarlara yön verme potansiyeline sahiptir (Tweneboah, Junior ve Oseifuah, 2019). 
Kalhoro ve arkadaşları çalışmalarında gelişmiş ekonomilerdeki (ABD, İngiltere ve AB) ekonomi politikası belirsizliğinin (EPU) SAARC (Pakistan, Hindistan, Sri Lanka ve Bangladeş) ülkeleri ile borsa ilişkilerini nasıl etkilediğini araştırmaktadır. Borsalar arasında etkileşim ile portföy çeşitlendirme imkanı araştırılmıştır. 19972015 yılları arasında AGDCC-GARCH modeliyle SAARC'nin gelişmiş ekonomilerle borsa ilişkisi incelenmiştir. Araştırmanın bulgularına göre gelişmiş ekonomilerin politikalarının, Pakistan hisse senedi piyasası üzerinde negatif bir etkiye sahip olduğu tespit edilmiştir. Hindistan-ABD, Hindistan-İngiltere, Bangladeş- $A B$, Sri Lanka-ABD ve Sri Lanka-AB arasında pozitif yönlü ilişkiye rastlanmıştır. Ayrıca Hindistan$A B$, Bangladeş-ABD, Bangladeş-İngiltere ve Sri Lanka-İngiltere arasında herhangi bir etkileşim yoktur (Kalhoro, Oad Rajput ve Suleman, 2019).

Batı Avrupa ülkeleri olan Fransa ve Belçika borsaları arasındaki ilişkinin incelendiği çalışmada CAC40 ve BEL20 endeksleri değerlendirmeye alınmıştır. Veri seti 2000-2018 yıllarını kapsamaktadır. Çalışma sonunda BEL20 endeksinin öncü endeks olduğu ve çoğu zaman CAC40 endeksinin performansının, BEL20 endeksi hareketlerini takip ettiği belirlenmiştir (Verma A,\& Joseph T, 2019).

$\mathrm{Wu}$ ve arkadaşları araştırmalarında uluslararası borsaların birbiri ile ilişkisinde petrolün etkisini araştırmışlardır. Araştırmada petrol ihraç ve ithal eden ülkeler için MSCI endeksleri kullanılmıştır. Körfez İşbirliği Örgütü ve Rusya hisse senedi borsaları petrol ihraç eden ülkeler için, Çin, Amerika, Avrupa Birliği ve Japan borsaları ise petrol ithal eden ülkeler için kullanılmıştır. Petrol için ise Batı Texas Petrolü kullanılmıştır. Çalışmada kısmi ve çoklu dalgacık tutarlılık analizleri gerçekleştirilmiştir. Çalışmanın sonuçlarına göre; ham petrolün orta ve uzun vadede uluslararası borsalar arasındaki işbirliğini yönlendiren önemli bir faktör olduğunu görülmüştür (Wu, Zhu, $\mathrm{Xu}$ ve Yang, 2020).

\section{ARAŞTIRMA}

Çalışma Nasdaq OMX grubuna bağlı olan Avrupa borsaları arasındaki nedensellik ilişkilerinin incelenmesi amacıyla günlük borsa kapanış verileriyle yapılmaktadır.

\subsection{Veri Seti}

Nasdaq OMX çatısı altında yer alan NordicAll 40 ve bağlı endekslerden Copenhag20, Stockholm30, Helsinki25, Iceland8; Baltic10 ve bağlı endekslerden TallinSE General, Riga General ve VilniusSE General'in yanı sıra ayrıca 2 gruptan bağımsız olarak Oslo20 endeksine yer verilmiştir. Çalışmada 05.11.2013-10.10.2018 tarihleri arası günlük kapanış verilerinden yararlanılmış olup, 2 grup endeks (NordicAll40-Baltic10) 1 bağımsız endeks (Oslo20) ve Nordic ve Baltic grupları altında yer alan 7 endeks olmak üzere toplam 10 endekse yer verilmiştir.

Tablo 1. Veri Seti Tablosu

\begin{tabular}{|l|l|l|l|}
\hline Ülke & Endeks Ad1 & Bağlı Grup Endeksi & Verilerin Tarih Aralığ1 \\
\hline Danimarka & Copenhag20 & NordicALL40 & $05.11 .2013-10.10 .2018$ \\
\hline İsveç & Stockholm30 & NordicALL40 & $05.11 .2013-10.10 .2018$ \\
\hline Finlandiya & Helsinki25 & NordicALL40 & $05.11 .2013-10.10 .2018$ \\
\hline İzlanda & Iceland8 & NordicALL40 & $05.11 .2013-10.10 .2018$ \\
\hline Estonya & $\begin{array}{l}\text { TallinSE } \\
\text { General }\end{array}$ & Baltic10 & $05.11 .2013-10.10 .2018$ \\
\hline Letonya & Riga General & Baltic10 & $05.11 .2013-10.10 .2018$ \\
\hline Litvanya & $\begin{array}{l}\text { VilniusSE } \\
\text { General }\end{array}$ & Baltic10 & $05.11 .2013-10.10 .2018$ \\
\hline Norveç & OSLO20 & $\begin{array}{l}\text { Oslo20 (Bağımsiz } \\
\text { Borsa) }\end{array}$ & $05.11 .2013-10.10 .2018$ \\
\hline Nordic Grubu & NORDICALL40 & - & $05.11 .2013-10.10 .2018$ \\
\hline Baltic Grubu & BALTIC10 & - & $05.11 .2013-10.10 .2018$ \\
\hline
\end{tabular}

Tablo 1'de araştırmaya dahil edilen endeksler, bu endekslerin bağlı olduğu grup endeksleri ve ülkelere yer verilmiştir. 
T. Kocabıyık - T. Teker 12/2 (2020) 1459-1474

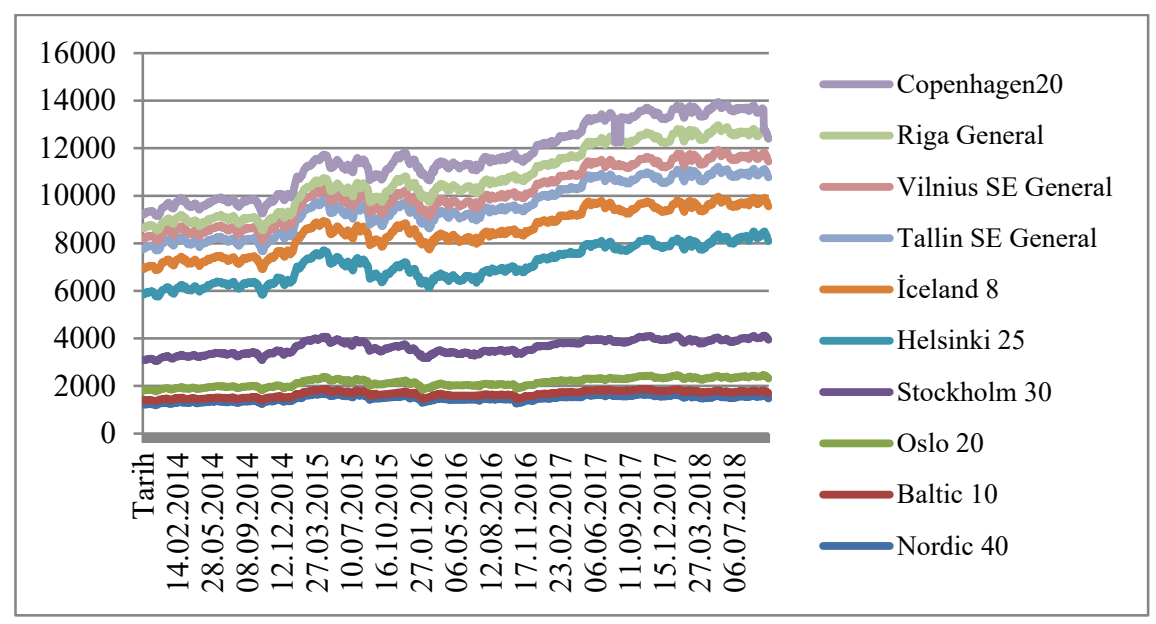

Grafik 2. Araştırmada Yer Alan Tüm Endekslerin Fiyat Grafikleri (2013-2018)

Yukarıdaki grafikte analize dahil edilen serilerin 2013-2018 yılları arasındaki fiyat grafiklerine yer verilmiştir. Grafik incelendiğinde bazı serilerin birlikte hareket eden gruplar oluşturdukları görülmüştür. Bunun da nedensellik ilişkisini işaret edebileceği düşüncesiyle araştırılmaya değer olduğu düşünülmüştür.

\subsection{Araştırma Dizaynı}

Çalışma 3 bölüme ayrılmıştır. İlk bölümde Nasdaq OMX grubuna bağlı olarak faaliyet gösteren Baltık Bölgesi ve Kuzey Avrupa Bölgesi (Nordic) borsalarının ana endeksleri olan Baltic10 ve NordicAll40 endeksleri ile bu 2 grubun dışında bağımsız olarak yer alan Norveç borsasının ana endeksi olan Oslo20 endeksi ele alınarak 3 endeks arasındaki ilişki incelenmektedir.

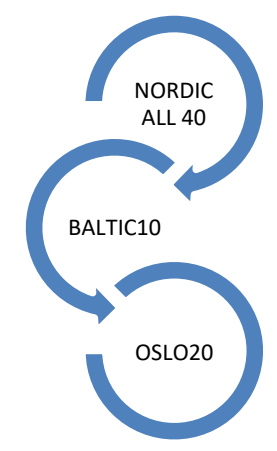

Grafik 3. Ana Karma Endeksler

2. aşamada Nasdaq OMX Nordic grubunun ana endeksi olan NordicAll40 ile bağlı endeksler Stockholm30, Copenhag20, Iceland8 ve Helsinki25 endeksleri incelenerek aralarındaki ilişki belirlenmeye çalışılmaktadır.

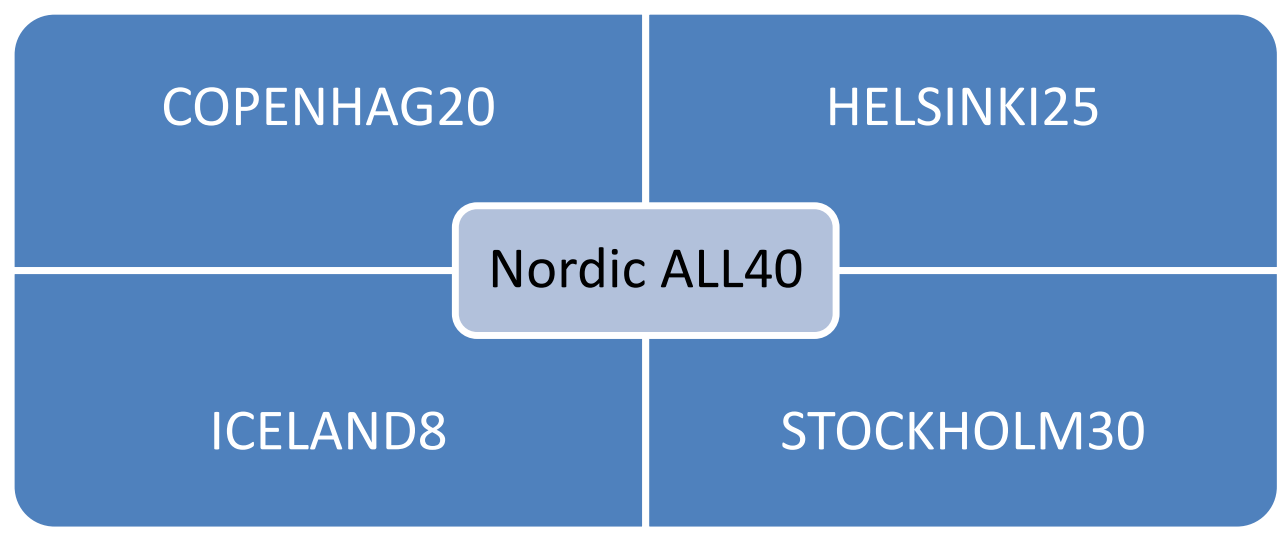

Grafik 4. NordicALL40 ve Bağlı Endeksler 
3. aşamada ise, Nasdaq OMX Baltic grubunun ana endeksi olan Baltic10 ile bağlı endeksler TallinSE General, Riga General ve VilniusSE General arasındaki ilişki incelenmektedir.

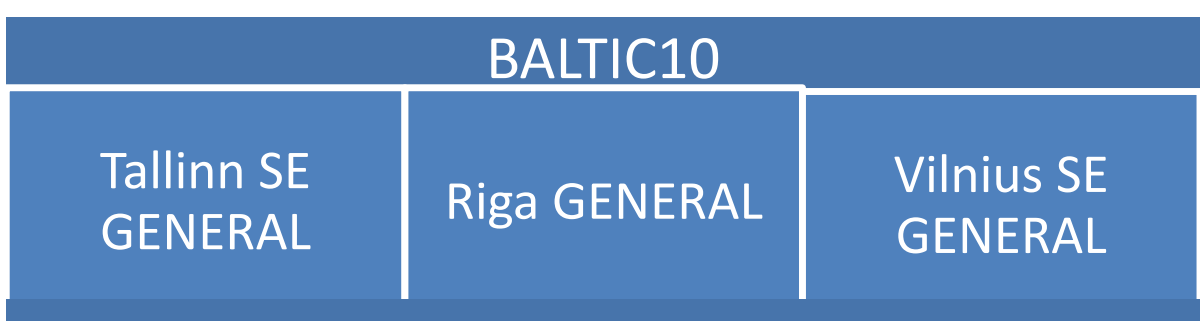

Grafik 5. Baltic10 ve Bağlı Endeksler

Seriler öncelikle Lee Strazicich kırılmalı birim kök testine tabi tutularak durağan oldukları seviye belirlenmiştir. Ardından optimal gecikme uzunlukları belirlenerek Toda-Yamamoto Analizi aracılığıla aralarındaki ilişki tespit edilmiştir.

\subsection{Metodoloji}

Seçilen borsa endeksleri arasındaki etkileşimi incelemek için zaman serisi analizlerinden yararlanılmıştır. Değişkenler arasındaki ilişkiyi araştırmak için öncelikle değişkenlerin durağan olup olmadığının test edilmesi gerekmektedir. Bu amaçla verilere yapısal kırılmaları dikkate alan Lee Strazicich (2003) birim kök testi uygulanmıştır. Ardından Akaike Bilgi Kriterine (AIC) göre optimal gecikme uzunluğu belirlenmiştir. Daha sonra değişkenler arasında herhangi bir nedensellik olup olmadığını ve varsa yönünü tespit edebilmek için Toda-Yamamoto analizi uygulanmıştır. Aşağıda bu çalışmada kullanılan model ve testlere ilişkin teorik bilgilere yer verilmiştir.

Bir serinin ortalamasının, varyansının ve kovaryansının zaman içerisinde aynı olması, geleceğe yönelik yapılacak tahminler için önemli bir koşuldur. Zaman serisi için istenen durum, serinin durağan olmasıdır. Ancak pek çok zaman serisi izlendiğinde, bu koşulu sağlamadıkları görülmektedir. Bu durumda yapılması gereken öncelikle durağan olmama durumu tespit edildikten sonra serinin durağan hale getirilmesidir (Bozkurt 2013: 33). Durağanlığı varsayım olarak kabul eden testlerde seriler durağanlaştırılmadan analiz yapılırsa sahte regresyona rastlanılabilir. Serilerin durağanlığını test edebilmek amaciyla uygulanan yöntemlerden biri birim kök testleridir. Birim kök testleri, serilerin durağanlığının ölçümünde sık kullanılırlar. Araştırmalarda kullanılan zaman serilerinde birim kök olması, durağan olmadıkları anlamına gelmektedir. Uygulanan birim kök testleri sonucunda, serilerin durağan olmaması halinde, serilerin farklarının alınması yoluna gidilebilir (Çelik 2011: 91).

Serilerin düzeylerinde durağan olmadığı halde birbirleri arasında bir bütünleşik yapının varlığının tespiti, varsa bu bütünleşik yapının ortaya çıkardığı doğrusal bileşenin (hata terimlerinin) durağanlığının test edilmesi, serilerin farkları alınmadan da ham verileriyle analizde kullanılabilmesine yardımcı olur. Şayet seriler arasında bir birlikte hareket etme davranışı yoksa o zaman serilerin durağanlığı sağlanana kadar farklarının alınması gerekecektir (Hatırlı, vd. 2008: 141).

Araştırmacılar, Perron (1989) çalışmasından beri, birim kök testlerinde yapısal kırılmaya izin vermenin önemi üzerinde durmaktadır. Perron (1989) yapısal kırılma ihmal edildiğinde, birim kök reddetme olasılığının düştüğünü yani testin gücünde bir azalma meydana geldiğini göstermiştir. Perron (1989) bilinen bir dışsal yapısal kırılmaya izin veren kukla değişken içeren düzeltilmiş Dickey Fuller (DF) birim kök testi kullanır. Sonraki çalışmalarda bu test, veriden içsel olarak belirlenen, bilinmeyen bir kırılma noktasına izin veren test olarak değiştirilmiştir. İçsel yöntemi yaygın olarak kullananlardan biri Zivot-Andrews (1992) minimum değer testidir. Bu test, t-istatistiği ile birim kök temel hipotezi test eder. T-değerinin en düşük değeri aldığı tarih, kırılma noktası olarak kabul edilir. Tek kırılmanın ihmal edildiği durumda testin gücü düştügüne göre iki veya daha fazla kırılma ihmal edilirse de benzer güç kayıplarını beklemek mantıklı olur. Lumsdaine-Papell (1997) bu yönde açıklamayı uzatır ve minimum Zivot-Andrews birim kök testini, iki yapısal kırılma içeren şekilde genişletmiştir (Lee ve Strazicich 2003: 1083).

Lee ve Strazicich tarafından geliştirilen tek kırılmalı LM testinde, ADF test tipinde olan Zivot ve Andrews testi ile karşılaştırarak, geliştirdikleri testin Zivot ve Andrews testine göre daha iyi sonuçlar verdiğini 
vurgulamışlardır. Lee ve Strazicich, çift kırılmayı dikkate alan ve kırılma noktasının bilinmediği, yeni bir birim kök testi geliştirmişlerdir. Bu çalışmada Lumsdaine-Papell testinin boyut bozulması sorunu olduğunu ifade etmişler ve geliştirdikleri LM tipi test ile bu sorunun önemli derecede ortadan kalktığını göstermişlerdir (Lee ve Strazicich 2003: 1083).

İki kırılmalı LM birim kök testi için kritik değerler Lee ve Strazicich (2003)'den elde edilirken, tek kırılmalı LM birim kök testi için kritik değerler Lee ve Strazicich (2004)'den elde edilir. Elde edilen test istatistiğinin kritik değerden büyük olması halinde yapısal kırılmalı birim kök temel hipotezi reddedilir (Yılancı 2009: 331).

Durağanlık testinden sonra değişkenler arasındaki nedensellik ilişkisini ortaya koyan Toda-Yamamoto testine geçilmiştir.

Bu model 1995 yılında Toda ve Yamamoto tarafından geliştirilmiş Granger nedensellik testinin genişletilmiş bir şeklidir. Bu test Granger Nedensellik Testi'nin karşılaştı̆̆ bazı sorunlardan kaçınmak için uygun bir modeldir. Granger Nedensellik Testi'nin uygulanabilmesi için serilerin durağan olması ya da aynı seviyede durağanlaşması gerekmektedir. Oysa farklı seviyede durağan olan seriler arasında da nedensellik olabileceği düşünülmektedir. Ayrıca Toda-Yamamoto yaklaşımının başka bir avantajı da sistemdeki eşbütünleşme bilgisini dikkate almadan, serilerin eşbütünleşik olup olmamasından bağımsız olarak test edilebilmesidir (Toda ve Yamamoto, 1995).

Toda-Yamamoto modeli, küçük gözlemlere sahip olan çalışmalarda daha etkin olup durağanlaşma seviyesi farklı olan serilerde kullanılabilir. Ayrıca ilişkisi incelenen serilerin eşbütünleşik olmasına gerek yoktur (Giles, 1997), (Mavrotas ve Kelly, 2001).

Toda-Yamamoto yöntemini uygulamak için öncelikle serilerin maksimum durağanlaşma seviyesinin ( $\mathrm{d}_{\max }$ ) ve VAR modelinin optimal gecikme uzunluğunun $(\mathrm{k})$ belirlenmesi gerekir. Toda-Yamamoto testi bir Wald Test istatistiği kullanarak hipotezin test edilmesini sağlar (Siami-Namini, 2017: 604). Nitekim Toda-Yamamoto metodunda öncelikle bir VAR modeli tahmin edilerek, optimum gecikme uzunluğu (k) belirlenmektedir ${ }^{1}$ (Yılmaz, 2018: 69). Maksimum gecikme uzunluğu (k) ya Schwarz Bilgi Kriteri (SIC) ya da Akaike Bilgi Kriteri (AIC) ile belirlenebilir (Lütkepohl 1991: 306).

Toda-Yamamoto (1995) tarafından geliştirilen VAR modeli aşă̆ıdaki denklemler yardımıyla uygulanmaktadır (Siami-Namini 2017: 604):

$$
\begin{gathered}
\mathrm{Yt}=a_{\mathrm{y}}+\sum_{i=1}^{k+d} \theta_{\mathrm{y}, \mathrm{i}} \mathrm{X}_{\mathrm{t}-\mathrm{i}}+\sum_{i=1}^{k+d} \vartheta_{\mathrm{y}, \mathrm{i}} \mathrm{Y}_{\mathrm{t}-\mathrm{i}}+\varepsilon_{\mathrm{y}, \mathrm{t}} \\
\mathrm{X}=a \mathrm{x}+\sum_{i=1}^{k+d} \theta \mathrm{x}, \mathrm{i} \mathrm{X} \mathrm{t}-\mathrm{i}+\sum_{i=1}^{k+d} \vartheta \mathrm{x}, \mathrm{i} \mathrm{Yt}-\mathrm{i}+\varepsilon \mathrm{X}, \mathrm{t}
\end{gathered}
$$

$Y^{\prime}$ den X'e doğru Granger nedenselliğin varlığını test etmek için Wald istatistiği kullanılarak $\lambda \mathbf{i} \neq 0$ sinırlaması test edilmektedir. X'ten Y'ye doğru nedenselliğin $\varphi \mathrm{i} \neq 0$ sınırlaması test edilmektedir (Bağdigen ve Beşer 200: 11).

Toda-Yamamoto testinde temel hipotez ve alternatif hipotez aşağıdaki gibi kurulur.

$H_{0}:$ A değ işkeni B değişkeninin Granger nedeni değildir.

$H_{1}:$ A değişkeni B değişkeninin Granger nedenidir.

Analiz bulgularında hesaplanan p olasılık değeri belirlenen istatistiki anlamlılık sınırının (\%1, \%5) altında ise $\mathrm{H}_{0}$ hipotezi reddedilebilir. Yani alternatif hipotez kabul edilir. P olasılık değeri belirlenen istatistiki anlamlılık sınırının üstünde ise $\mathrm{H}_{0}$ hipotezi reddedilemez. Yani A değişkeni B değişkeninin Granger nedeni değildir.

\subsection{Ampirik Bulgular}

$\mathrm{Bu}$ aşamada öncelikle birim kök testlerine yer verilmiş ardından değişkenler arasındaki nedensellik ilişkisi Toda-Yamamoto Testi ile araştırılmıştır.

\footnotetext{
${ }^{1}$ Gecikme uzunlukları; bağımlı değişkenin cari ( $t$ ) dönemdeki değeri üzerinde, bağımlı ve bağımsız değişkenin kaç dönem önceki değerinin etkisinin olduğunu göstermektedir.
} 
T. Kocabiyık - T. Teker 12/2 (2020) 1459-1474

\subsubsection{Lee-Strazicich Birim Kök Testleri}

Toda-Yamamoto (1995) nedensellik analizinin yapılabilmesi için öncelikle serilerin maksimum durağanlaştığı seviye ile optimal gecikme uzunluklarının belirlenmesi gerekmektedir. Serilerin durağanlaşma seviyeleri LeeStrazicich (2003) testi ile gecikme uzunlukları ise Akaike Bilgi Kriteri ile belirlenmiştir. Tablo 2' de birim kök testi sonuçları verilmiştir.

Tablo 2. Lee Strazicich Birim Kök Testi Sonuç Tablosu

\begin{tabular}{|c|c|c|c|c|}
\hline \multicolumn{5}{|c|}{ Lee Strazicich Birim Kök Testi Sonuç Tablosu } \\
\hline \multirow[b]{2}{*}{ Değişken } & Düzey & \multirow{2}{*}{$\begin{array}{l}\text { Kritik } \\
\text { Değer }\end{array}$} & 1. Fark & \multirow[b]{2}{*}{ Kritik Değer } \\
\hline & $\begin{array}{c}\text { Test } \\
\text { İstatistiği }\end{array}$ & & $\begin{array}{c}\text { Test } \\
\text { İstatistiği }\end{array}$ & \\
\hline NORDICALL40 & $-3,539$ & $-3,956$ & $-19,876$ & $-3,989$ \\
\hline BALTIC10 & $-2,547$ & $-4,049$ & $-18,660$ & $-3,925$ \\
\hline OSLO20 & $-4,307$ & $-4,043$ & & \\
\hline Copenhag20 & $-4,175$ & $-3,968$ & & \\
\hline Helsinki25 & $-3,850$ & $-4,026$ & $-18,000$ & $-3,975$ \\
\hline Iceland8 & $-3,140$ & $-4,028$ & $-12,542$ & $-3,977$ \\
\hline Stockholm30 & $-3,107$ & $-4,021$ & $-19,294$ & $-3,952$ \\
\hline TallinSE General & $-2,726$ & $-3,971$ & $-14,280$ & $-3,926$ \\
\hline Riga General & $-2,340$ & $-4,024$ & $-11,954$ & $-3,987$ \\
\hline VilniusSE General & $-3,048$ & $-3,995$ & $-18,455$ & $-3,919$ \\
\hline
\end{tabular}

*: \%5 seviyesinde anlamlıdır.

Birim kök testi sonuçlarına göre Oslo20 ve Copenhag20 endeksleri düzey değerlerinde durağandır. Diğer endeksler ise düzey değerlerinde durağan değilken, 1. Farkta durağan hale gelmektedir.

\subsubsection{Grup Endeksleri Toda-Yamamoto Nedensellik Testi Sonuçları}

Bu bölümde çalışmanın ilk analiz bölümünü oluşturan grup endeksleri analize dahil edilmiştir. NordicALL40, Baltic10 ve 2 gruptan bağımsız olan Norveç Borsasının ana endeksi olan Oslo20 arasındaki ilişki TodaYamamoto metodolojisine uygun olarak analiz edilmiştir. Analize geçmeden ilgili 3 endeksin fiyat grafiği incelenmiştir.

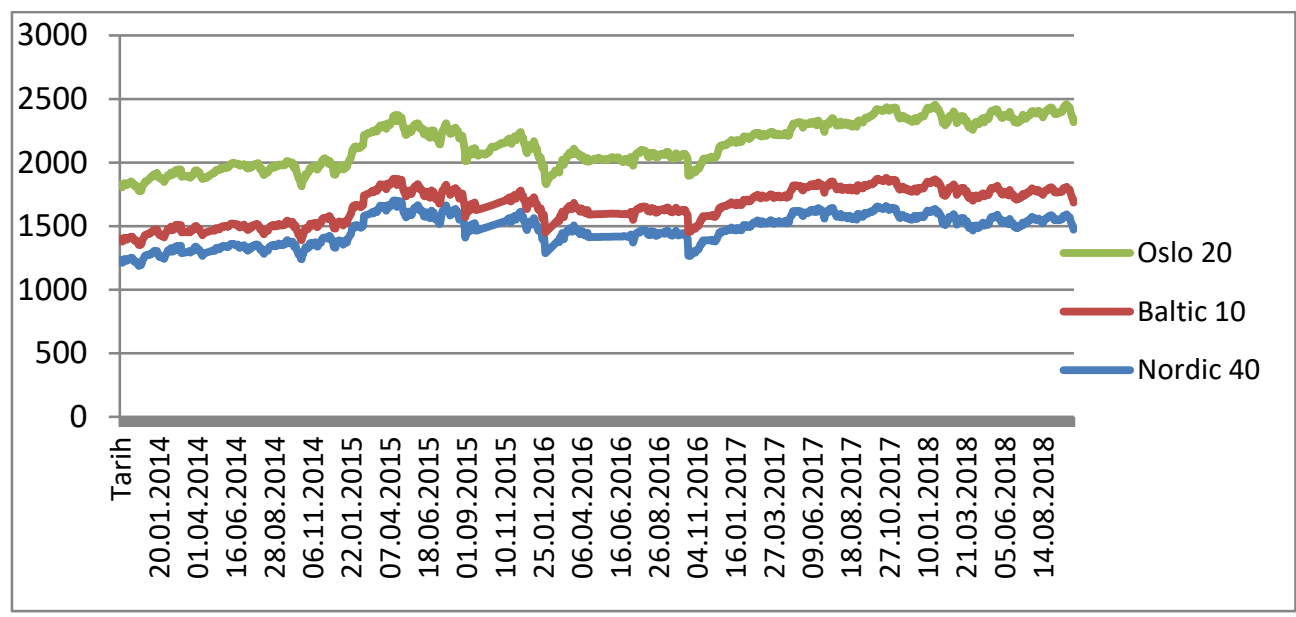

Grafik 6. Grup Endeksleri Fiyat Grafiği (2013-2018)

Yukarıdaki grafikte Nordic40, Baltic10, Oslo20 endekslerine ait fiyat hareketlerine yer verilmiştir. Grafikte, 2013-2018 yılları arasında, ele alınan serilerin birlikte hareket ettiklerine ilişkin ipuçları görülmektedir. 
T. Kocabiyık - T. Teker 12/2 (2020) 1459-1474

Tablo 3. Grup Endeksleri Toda-Yamamoto Nedensellik Testi Sonuç Tablosu

\begin{tabular}{|c|c|c|c|c|c|c|}
\hline Bağımlı Değişken & $\begin{array}{l}\text { Bağımsız } \\
\text { Değişken }\end{array}$ & dmax & $\mathbf{k}$ & $\begin{array}{c}\text { Ki-Kare } \\
\text { Test } \\
\text { İstatistiği }\end{array}$ & $\begin{array}{c}\text { Ki- } \\
\text { Kare } \\
\text { P- } \\
\text { değeri }\end{array}$ & İlişki ve Yönü \\
\hline \multirow{2}{*}{ NORDICALL40 } & BALTIC10 & \multirow{2}{*}{1} & \multirow{2}{*}{5} & 20,733 & 0,0009 & BALTIC10 $\rightarrow$ NORDICALL40 \\
\hline & OSLO20 & & & 2,665 & 0,7514 & Yok \\
\hline \multirow{2}{*}{ BALTIC10 } & NORDICALL40 & \multirow{2}{*}{1} & \multirow{2}{*}{5} & 9,788 & 0,0815 & Yok \\
\hline & OSLO20 & & & 6,032 & 0,3031 & Yok \\
\hline \multirow{2}{*}{ OSLO20 } & NORDICALL40 & \multirow{2}{*}{1} & \multirow{2}{*}{5} & 100,590 & 0,0000 & NORDICALL40 $\rightarrow$ OSLO20 \\
\hline & BALTIC10 & & & 16,513 & 0,0055 & BALTIC10 $\rightarrow$ OSLO20 \\
\hline
\end{tabular}

Nordic 40, Baltic 10 ve Oslo 20 serileri arasındaki nedenselliği incelemek için Toda-Yamamoto Modelinden yararlanılmıştır. Toda-Yamamoto testi yapılırken serilerin gecikme uzunluğu (k) Akaike Bilgi Kriterine (AIC) göre, maksimum bütünleşme derecesi dmax ise Lee-Strazicich (LS) birim kök testine göre bulunmuştur. Sonra bu modeldeki k gecikmeli değerlere Wald istatistiği uygulanarak nedensellik ilişkisinin olup olmadığı tespit edilmeye çalışılmıştır. Elde edilen bulgulara göre; Baltic10'dan NordicAll40'a doğru, NordicAll40'dan Oslo20'ye doğru ve Baltic10'dan Oslo20'ye doğru nedensellik ilişkisine rastlanmıştır. Osla20 endeksinin bağımsız değişken olarak bağımlı değişkenleri etkilemediği görülmüştür. Baltic10 endeksinin ise bağımsız değişken olarak hem NordicAll40 endeksini hem de Oslo20 endeksini etkilediği görülmüştür.

\subsubsection{Nordic Grubu Toda-Yamamoto Nedensellik Testi Sonuçları}

Ekonometrik analize geçmeden önce, çalışmaya dahil edilen endekslerin günlük fiyatlarının seyri incelenmiştir.

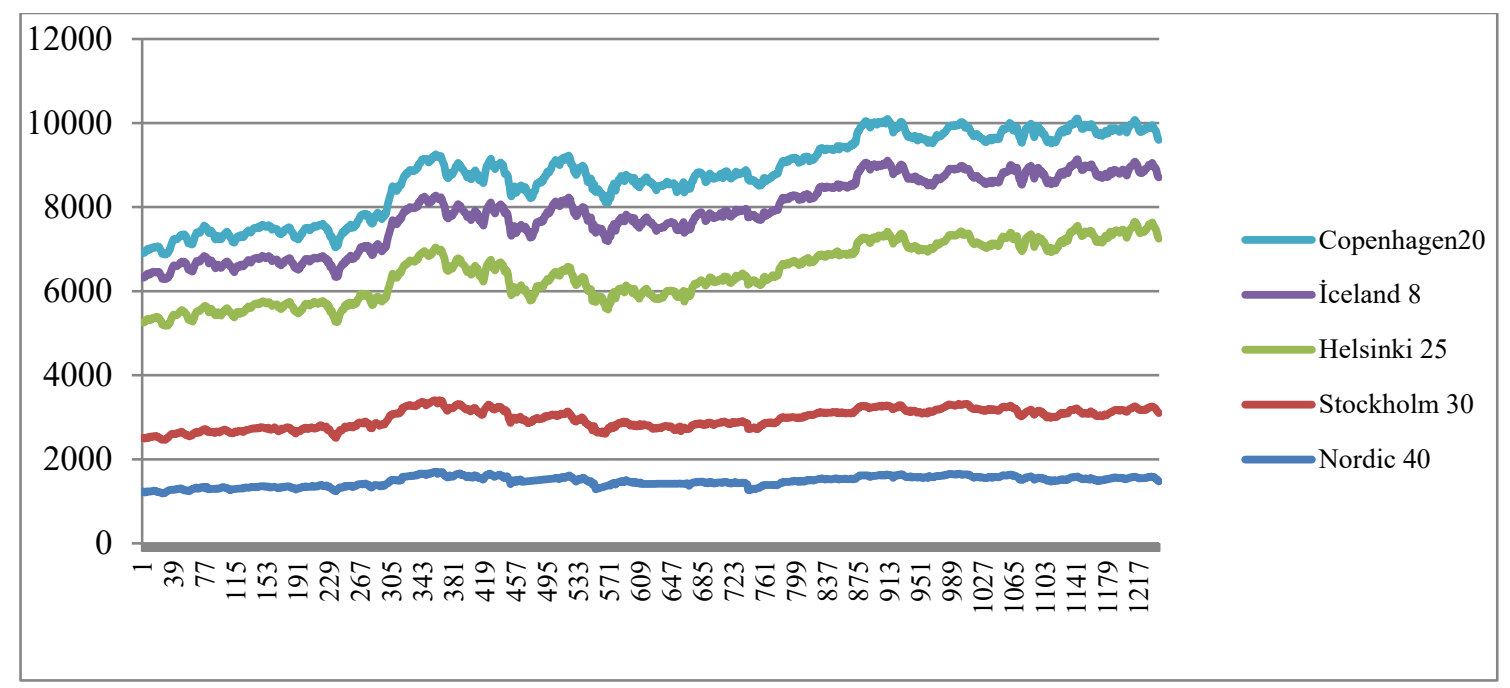

Grafik 7. Borsa Endekslerinin 2013-2018 Arası Fiyat Grafiği (Nordic Grubu)

Şekil 7'de Nordic40, Copenhagen20, Iceland8, Helsinki25, Stockholm30 serilerine ait 2013-2018 dönemi fiyat hareketlerine yer verilmiştir. Tüm endekslerin fiyat grafikleri arasındaki benzerlik göze çarpmaktadır. 
T. Kocabiyık - T. Teker 12/2 (2020) 1459-1474

Tablo 4. Nordic Grubu Toda-Yamamoto Nedensellik Testi Sonuç Tablosu

\begin{tabular}{|c|c|c|c|c|c|c|}
\hline Bağımlı Değişken & $\begin{array}{l}\text { Bağımsız } \\
\text { Değişken }\end{array}$ & dmax & k & $\begin{array}{c}\text { Ki-Kare } \\
\text { Test } \\
\text { İstatistiği }\end{array}$ & $\begin{array}{c}\text { Ki-Kare P- } \\
\text { değeri }\end{array}$ & İlişki ve Yönü \\
\hline \multirow{4}{*}{ NORDICALL40 } & Copenhag20 & \multirow{4}{*}{1} & \multirow{4}{*}{7} & 50,220 & 0,000 & Copenhag20 $\rightarrow$ NORDICALL40 \\
\hline & Helsinki25 & & & 7,749 & 0,355 & Yok \\
\hline & Iceland8 & & & 6,327 & 0,502 & Yok \\
\hline & Stockholm30 & & & 134,247 & 0,000 & Stockholm $30 \rightarrow$ NORDICALL40 \\
\hline \multirow{4}{*}{ Copenhag20 } & NORDICALL40 & \multirow{4}{*}{1} & \multirow{4}{*}{7} & 38,628 & 0,000 & NORDICALL40 $\rightarrow$ Copenhag20 \\
\hline & Helsinki25 & & & 13,672 & 0,057 & Yok \\
\hline & Iceland8 & & & 3,315 & 0,854 & Yok \\
\hline & Stockholm30 & & & 5,255 & 0,628 & Yok \\
\hline \multirow{4}{*}{ Helsinki25 } & NORDICALL40 & \multirow{4}{*}{1} & \multirow{4}{*}{7} & 62,142 & 0,000 & NORDICALL40 $\rightarrow$ Helsinki25 \\
\hline & Copenhag20 & & & 4,093 & 0,768 & Yok \\
\hline & Iceland8 & & & 3,559 & 0,828 & Yok \\
\hline & Stockholm 30 & & & 446,507 & 0,000 & Stockholm30 $\rightarrow$ Helsinki25 \\
\hline \multirow{4}{*}{ Iceland8 } & NORDICALL40 & \multirow{4}{*}{1} & \multirow{4}{*}{7} & 3,220 & 0,863 & Yok \\
\hline & Copenhag20 & & & 4,566 & 0,712 & Yok \\
\hline & Helsinki25 & & & 18,265 & 0,010 & Helsinki25 $\rightarrow$ Iceland8 \\
\hline & Stockholm 30 & & & 8,964 & 0,255 & Yok \\
\hline \multirow{4}{*}{ Stockholm30 } & NORDICALL40 & \multirow{4}{*}{1} & \multirow{4}{*}{7} & 14,551 & 0,042 & NORDICALL40 $\rightarrow$ Stockholm30 \\
\hline & Copenhag20 & & & 117,028 & 0,000 & Copenhag $20 \rightarrow$ Stockholm30 \\
\hline & Helsinki25 & & & 6,402 & 0,493 & Yok \\
\hline & Iceland8 & & & 4,518 & 0,718 & Yok \\
\hline
\end{tabular}

Nordic 40, Copenhag20, Helsinki25, Iceland8 ve Stockholm30 serileri arasındaki nedenselliği incelemek için Toda-Yamamoto Modelinden yararlanılmıştır. Toda-Yamamoto testi yapılırken serilerin gecikme uzunluğu (k) Akaike Bilgi Kriterine (AIC) göre, maksimum bütünleşme derecesi dmax ise Lee-Strazicich (LS) birim kök testine göre bulunmuştur. Sonra bu modeldeki k gecikmeli değerlere Wald istatistiği uygulanarak nedensellik ilişkisinin olup olmadığı tespit edilmeye çalışılmıştır. Elde edilen bulgulara göre; Copenhag20 ve NordicAll40 endeksleri ile Stockholm30 ve NordicAll40 endeksleri arasında iki yönlü nedenselliğe rastlanmıştır. Ayrıca NordicAll40 endeksinden Helsinki25 endeksine, Stockholm30 endeksinden Helsinki25 endeksine, Helsinki25 endeksinden Iceland8 endeksine ve Copenhag20 endeksinden Stockholm30 endeksine doğru tek yönlü nedenselliğe rastlanmıştır.

\subsubsection{Baltic Grubu Toda-Yamamoto Nedensellik Testi Sonuçları}

Baltic Grubu endekslerin fiyat grafikleri Şekil 8'de sunulmuştur. Grafiklerde görülen benzer hareket nedensellik analizine yönelmemizi sağlamaktadır. 
T. Kocabiyık - T. Teker 12/2 (2020) 1459-1474

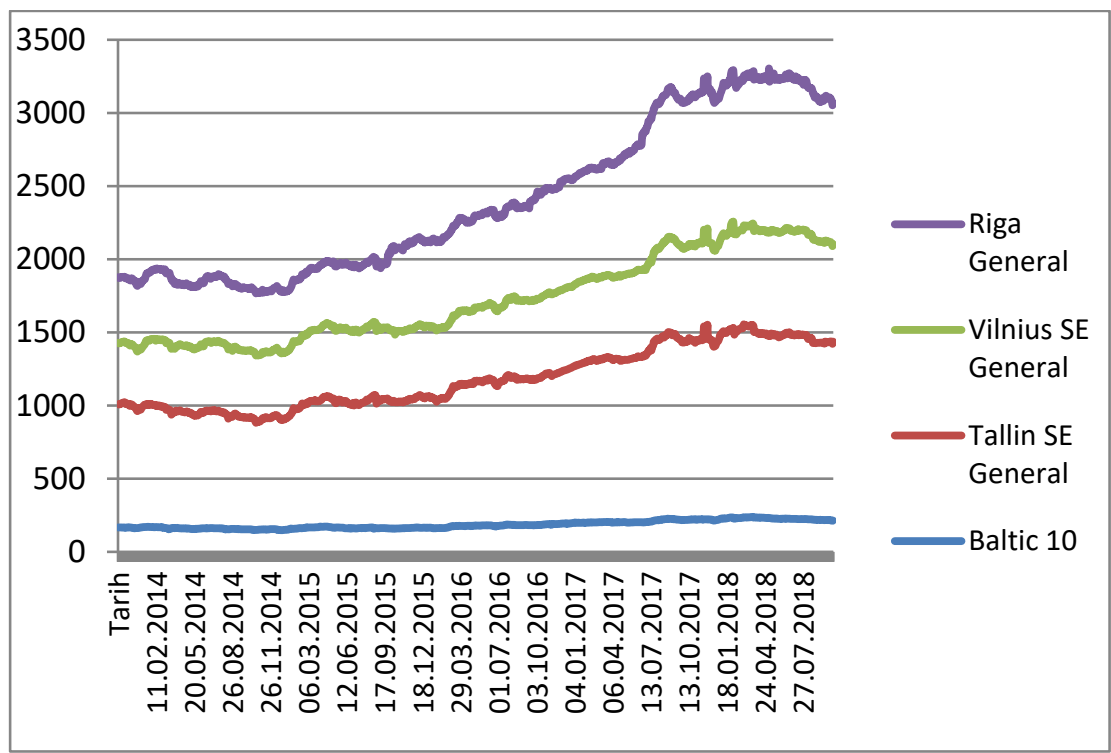

Grafik 8. Borsa Endekslerinin 2013-2018 Arası Fiyat Grafiği (Baltic Grubu)

Baltic10, TallinSE General, Riga General ve VilniusSE General serileri arasındaki nedenselliği incelemek için Toda-Yamamoto Modelinden yararlanılmıştır. Toda-Yamamoto testi yapılırken serilerin gecikme uzunluğu (k) Akaike Bilgi Kriterine (AIC) göre, maksimum bütünleşme derecesi dmax ise Lee-Strazicich (LS) birim kök testine göre bulunmuştur. Sonra bu modeldeki k gecikmeli değerlere Wald istatistiği uygulanarak nedensellik ilişkisinin olup olmadığı tespit edilmeye çalışılmıştır. Elde edilen bulgular Tablo 5'te sunulmuştur.

Tablo 5. Baltic Grubu Toda-Yamamoto Nedensellik Testi Sonuç Tablosu

\begin{tabular}{|c|c|c|c|c|c|c|}
\hline $\begin{array}{c}\text { Bağımlı } \\
\text { Değişken }\end{array}$ & $\begin{array}{l}\text { Bağımsız } \\
\text { Değişken }\end{array}$ & dmax & $\mathbf{k}$ & $\begin{array}{c}\text { Ki-Kare Test } \\
\text { İstatistiği }\end{array}$ & $\begin{array}{l}\text { Ki-Kare } \\
\text { P-değeri }\end{array}$ & İlişki ve Yönü \\
\hline \multirow{3}{*}{ BALTIC10 } & $\begin{array}{l}\text { TallinSE } \\
\text { General }\end{array}$ & \multirow{3}{*}{1} & \multirow{3}{*}{9} & 23,398 & 0,005 & $\begin{array}{l}\text { TallinSE General } \rightarrow \\
\text { BALTIC10 }\end{array}$ \\
\hline & Riga General & & & 6,242 & 0,715 & Yok \\
\hline & $\begin{array}{c}\text { VilniusSE } \\
\text { General } \\
\end{array}$ & & & 24,317 & 0,004 & $\begin{array}{c}\text { VilniusSE General } \rightarrow \\
\text { BALTIC10 } \\
\end{array}$ \\
\hline \multirow{3}{*}{ TallinSE General } & BALTIC10 & \multirow{3}{*}{1} & \multirow{3}{*}{9} & 221,435 & 0,000 & $\begin{array}{l}\text { BALTIC10 } \rightarrow \text { TallinSE } \\
\text { General }\end{array}$ \\
\hline & Riga General & & & 8,306 & 0,503 & Yok \\
\hline & $\begin{array}{c}\text { VilniusSE } \\
\text { General } \\
\end{array}$ & & & 12,078 & 0,208 & Yok \\
\hline \multirow{3}{*}{ Riga General } & BALTIC10 & \multirow{3}{*}{1} & \multirow{3}{*}{9} & 12,448 & 0,189 & Yok \\
\hline & $\begin{array}{l}\text { TallinSE } \\
\text { General } \\
\end{array}$ & & & 18,228 & 0,032 & $\begin{array}{c}\text { TallinSE General } \rightarrow \text { Riga } \\
\text { General }\end{array}$ \\
\hline & $\begin{array}{l}\text { VilniusSE } \\
\text { General } \\
\end{array}$ & & & 14,336 & 0,110 & Yok \\
\hline \multirow{3}{*}{$\begin{array}{c}\text { VilniusSE } \\
\text { General }\end{array}$} & BALTIC10 & \multirow{3}{*}{1} & \multirow{3}{*}{9} & 26,034 & 0,002 & $\begin{array}{c}\text { BALTIC10 } \rightarrow \text { VilniusSE } \\
\text { General } \\
\end{array}$ \\
\hline & $\begin{array}{l}\text { TallinSE } \\
\text { General } \\
\end{array}$ & & & 25,277 & 0,003 & $\begin{array}{l}\text { TallinSE General } \rightarrow \\
\text { VilniusSE General }\end{array}$ \\
\hline & Riga General & & & 18,514 & 0,030 & $\begin{array}{c}\text { Riga General } \rightarrow \text { VilniusSE } \\
\text { General }\end{array}$ \\
\hline
\end{tabular}

Tablo 5'e göre TallinSE General endeksi ile Baltic10 endeksi ve VilniusSE General ile Baltic10 endeksleri arasında karşılıklı nedensellik ilişkisi tespit edilmiştir. Ayrıca TallinSE General endeksinden Riga General 
endeksine, yine TallinSE General endeksinden VilniusSE General endeksine ve Riga General endeksinden VilniusSE General endeksine doğru tek yönlü nedensellik ilişkisine rastlanmıştır.

\section{SONUÇ VE TARTIŞMA}

Dünyanın teknoloji borsası olarak bilinen Nasdaq, 1984 yılında kurulup 2004 yılında OMX AB ismini alan Stockholm merkezli şirketi 2008 yılında satın almışır. Bu şirket, birçok Kuzey Avrupa borsasını işletme hakkını elinde bulundurmaktadır. Nasdaq OMX çatısı altında faaliyetlerini sürdüren borsalar Baltic ve Nordic grubu altında sınıflandırılmaktadır. Aynı zamanda Norveç borsası da bu 2 gruptan bağımsız olarak Nasdaq OMX bünyesinde yer almaktadır.

Bu çalışmada Nasdaq OMX çatısı altında yer alan borsaların ve aynı zamanda NordicAll40 ve Baltic10 grup endeksleri arasındaki ilişkinin belirlenmesi hedeflenmiştir. Çalışma 3 bölüme ayrılarak ilk bölümde Nasdaq OMX bünyesinde yer alan 2 grup endeksi NordicALL40, Baltic10 ve bağımsız endeks Oslo20 arasındaki ilişki incelenmiştir.

Analiz sonucunda; Baltic10 endeksi, grup endeksleri arasında dominant bir endekstir. Hem NordicAll40 endeksi hem de Oslo20 endeksi ile nedensellik ilişkisi söz konusudur. Ayrıca Baltic10 endeksinin ne NordicAll40 endeksinden ne de Oslo20 endeksinden etkilenmediği görülmüştür. Oslo20 endeksi diğer grup endekslerinin nedeni değilken, kendisi hem NordicAll40 endeksinden hem de Baltic10 endeksinden etkilenmektedir. Nordic Grubu incelendiğinde, Iceland8 endeksi dışında diğer endekslerin NordicAll40 endeksinden etkilendiği görülmüştür. Copenhag20 endeksinin, NordicAll40 endeksi dışında bir endeks ile nedensellik ilişkisine rastlanmamıştır. Iceland 8 endeksi herhangi bir endeksin Granger nedeni değildir. Baltic Grubu endeksleri incelendiğinde, VilniusSE General endeksinin diğer endekslerden ve ana endeks Baltic10 endeksinden etkilendiği görülmektedir.

Birbirine yakın coğrafyalarda bulunan Nordic ülkeleri ve Baltic ülkeleri borsa endeksleri arasında bazı nedensellik ilişkileri tespit edilmiştir. Bu sonuçlar literatürde Chan vd. (1997), Worthington ve Higgs (2007), Choudhry vd. (2007), Çelik ve Boztosun (2010), Verma ve Joseph (2019), Angelovska (2017), Pietrzak (2017), Tweneboah vd. 2019 ve Verma ve Joseph (2019) çalışmaları ile benzerlik göstermektedir. Kimi endeksler arasında ise herhangi bir ilişkiye rastlanmamıştır. Bu sonuçlara göre yatırımcılar portföy çeşitlendirmesi yaparken nedensellik ilişkisi olmayan endekslere yatırım yapmalıdır. Ayrıca borsa birleşmelerinin endeksler arasındaki nedensellik ilişkilerini tetiklediği görülmektedir.

\section{Kaynaklar}

Akel, V. (2015), Kırılgan Beşli Ülkelerinin Hisse Senedi Piyasaları Arasındaki Eşbütünleşme Analizi, Uluslararası Yönetim İktisat ve İşletme Dergisi, 11(24), 75-96.

Alvi A.M., Chughtai S.H., Haq U.A.,(2015) Co-Movement of Pakistan Stock Market with the Stock Markets of Major Developed Countries which have Portfolio Investment in Pakistan, Management Studies and Economic Systems (MSES), 2 (1), 347-360, Summer 2015

Angelovska Julijana, (2017), Long and Short-Term Dynamic Relationship between Macedonian and Croatian Stock Markets, Zagreb International Review of Economics \& Business, Vol. 20, No. 2, pp. 11-20, DOI: 10.1515/zireb-2017-0014

Bağdigen, M. ve Beşer, B. (2009), Ekonomik Büyüme ile Kamu Harcamaları Arasındaki Nedensellik İlişkisinin Wagner Tezi Kapsamında Bir Analizi: Türkiye Örneği. ZKÜ Sosyal Bilimler Dergisi, 5(9), 1-17.

Bekaert, G. and Campbell, R.H. (1995), Time-varying world market integration, The Journal of Finance, Vol. 50 No. 2, pp. 403-44.

Bloomberg, https://www.bloomberg.com/research/stocks/private/snapshot.asp?privcapId=671762 (Erişim Tarihi 3 Aralık 2018)

Boujir, A. and Lahrech, A. (2008), Morocco \& US equity markets linkage after FTA signature-implications for international portfolio diversification, International Research Journal of Finance and Economics, Vol. 21, pp. 112-23.

Bozkurt, H. Y. (2013), Zaman Serileri Analizi, Bursa: Ekin Basım Yayın Dağıtım, 
Bulut, Ş.ve Özdemir A. (2014), İstanbul Menkul Kıymetler Borsası ve Dow Jones Industrial Arasındaki İlişki: Eşbütünleşme Analizi. Yönetim ve Ekonomi: Celal Bayar Üniversitesi İktisadi ve İdari Bilimler Fakültesi Dergisi, 19 (1), 211-224. Retrieved from http://dergipark.gov.tr/yonveek/issue/13696/165768

Chan Kam C., Gup Benton E., Shiun Pan Ming, (2003), International Stock Market Efficiency and Integration: A Study of Eighteen Nations, Journal of Business Finance \& Accounting, 24(6), July 1997, 0306-686X

Chittedi, K. R. (2009). Global stock markets development and integration: With special reference to BRIC countries https://mpra.ub.uni-muenchen.de/18602/1/MPRA_paper_18602.pdf

Choudhry, T. (1996), Interdependence of stock markets: evidence from Europe during the 1920s and 1930s, Applied Financial Economics, Vol. 6 No. 3, pp. 243-9.

Choudhry, Taufiq \& Lu, Lin \& Peng, Ke, 2007. Common stochastic trends among Far East stock prices: Effects of the Asian financial crisis, International Review of Financial Analysis, Elsevier, vol. 16(3), pages 242261.

Çelik, İ. (2011), Vadeli İşlem Piyasasında Fiyat Keşfi: İzmir Vadeli İşlem ve Opsiyon Borsasında Ampirik Bir Uygulama. Isparta: Süleyman Demirel Üniversitesi, Sosyal Bilimler Enstitüsü, İşletme Anabilim Dalı / Muhasebe Finansman Bilim Dalı (Doktora Tezi) .

Çelik, T.ve Boztosun D. (2010), Türkiye Borsası ile Asya Ülkeleri Borsaları Arasındaki Entegrasyon İlişkisi. Erciyes Üniversitesi İktisadi ve İdari Bilimler Fakültesi Dergisi, 0 (36), 57-71.

Giles, D. (1997), Causality Between the Measured and Underground Economies in New Zealand. Applied Economics Letters, 4(1), 63-67.

Gilmore, C., Lucey, B.M., McManus,G M., (2005). The Dynamics of Central European Equity Market Comovements, The Quarterly Review of Economics and Finance, 48 (2008) 605-622

Gözbaşı, O. (2010), İMKB ile Gelişmekte Olan Ülkelerin Hisse Senedi Piyasalarının Etkileşimi: Eşbütünleşme ve Nedensellik Yaklaşımı. Erciyes Üniversitesi İktisadi ve İdari Bilimler Fakültesi Dergisi, (35), 99-118.

Hamao, Y., Masulis, R.W. and Ng, V. (1990), Correlation in price changes and volatility across international stock markets, The Review of Financial Studies, Vol. 3 No. 2, pp. 281-307.

Hatırlı, S. A., Öztürk, E., Aktaş, A. R. (2008), Fındık Piyasasında Fiyat Geçirgenliğinin Analizi. Akdeniz Üniversitesi Ziraat Fakültesi Dergisi, 21(1), 139-143.

Iqbal A., Khalid N., Rafiq S. (2011), Dynamic Interrelationship among the Stock Markets of India, Pakistan and United States, International Journal of Human and Social Sciences 6:1 2011

Jeon, B.N. and Chiang, T.C. (1991), A system of stock prices in world stock exchange: common stochastic trends for 1975-1990, Journal of Economics and Business, Vol. 43, pp. 329-38.

Kalhoro, M. R., Oad Rajput, S. K. ve Suleman, T. (2019). Dynamic Linkages Between Economic Policy Uncertainty and Stock Market Interdependence: Empirical Evidence From SAARC Region. SSRN Electronic Journal. doi:10.2139/ssrn.3554227

Kılıç, R. ve Dilber, C. (2017), Türkiye ve BRICS Ülkelerinin Finansal Piyasaları Arasındaki İlişkinin Kantil Regresyon Yöntemi İle İncelenmesi, Akademik Sosyal Araştırmalar Dergisi, 5(48), 331-342.

Lee, J. ve Strazizich, M.C. (2004), Minimum LM Unit Root Test with One Structural Break. Appalachian State University Working Papers, 4(17), 1- 15.

Lee, J.ve Strazizich, M. (2003), Minimum Lagrange Multiplier Unit Root Test with Two Structural Break, Review of Economics and Statistics, 85, 1082-1089.

Lumsdaine, R.L. ve Papell, D.H. (1997). Multiple Trend Breaks and The Unit Root Hypothesis. The Review of Economics and Statistics,79(2),212- 218.

Lütkepohl , H. (1991), Introduction to Multiple Time Series Analysis, Berlin Heidelberg: Springer.

Mavrotas, G. ve Kelly, R. (2001), Old wine in new bottles: Testing causality between savings and growth. The Manchester School, 69, 97-105. doi:10.1111/1467-9957.69.s1.6

Mohanasundaram, T. ve Karthikeyan, P. Cointegration and stock market interdependence: Evidence from South Africa, India and the USA. S. Afr. j. econ. manag. sci. [online]. 2015, vol.18, n.4 [cited 2019-0911], pp.475-485. Available from: <http://www.scielo.org.za/scielo.php?script=sci_arttext\&pid=S2222- 
34362015000400003\&lng=en\&nrm=iso>. ISSN 2222-3436. http://dx.doi.org/10.17159/22223436/2015/V18N4A3.

Nasdaq, https://business.nasdaq.com/discover (Erişim Tarihi 3 Aralık 2018)

Öner H. (2018), Kırılgan Beşli Ülkelerin Borsa Endeksleri Arasında Nedensellik İlişkisi: Ampirik Bir Analiz. İktisat Politikası Araştırmaları Dergisi, 5 (2), 152-166. Retrieved from http://dergipark.gov.tr/iuipad/issue/38690/428640

Perron, P. (1989), The Great Crash, the Oil Price Shock, and the Unit Root Hypothesis, Econometrica,57(6),1361-1401.

Pietrzak, M. B., Fałdziński, M., Balcerzak, A. P., Meluzín, T., Zinecker, M. (2017), Short-term Shocks and Longterm Relationships of Interdependencies Among Central European Capital Markets, Economics and Sociology, Vol. 10, No. 1, pp. 61-77. DOI: 10.14254/2071-789X.2017/10-1/5

Sharma, A. ve Seth, N. (2012). Literature review of stock market integration: A global perspective. Qualitative Research in Financial Markets, 4(1), 84-122. doi:10.1108/17554171211213568

Siami-Namini, S. (2017), Granger Causality Between Exchange Rate and Stock Price: A Toda Yamamoto Approach. International Journal of Economics and Financial Issues, 7(4), 603-607.

Sriram P. (2017), An Empirical Study on the Interdependence among Stock Market, Commodities Market and Foreign Exchange Market, IOSR Journal of Economics and Finance (IOSR-JEF) e-ISSN: 2321-5933, pISSN: 2321-5925.8(4), (Jul.- Aug.2017), 01-07.

Toda, H., \& Yamamoto, T. (1995), Statistical inference in vector autoregressions with possibly integrated processes. Journal of Econometrics, 66, 225-250.

Türkiye Sermaye Piyasaları Birliği,(2011), Dünyada Borsa Şirketleşmeleri, Satın Alma Ve Birleşmeleri https://www.tspb.org.tr/wp-

content/uploads/2015/06/AIM_Yayin_ve_Raporlar_Arastirma_Raporlari_Borsa_Sirketlestirmeleri.pd $\mathrm{f}$

Tweneboah, G., Junior, P. O. ve Oseifuah, E. K. (2019). Integration of Major African Stock Markets: Evidence From Multi-Scale Wavelets Correlation, Academy of Accounting and Financial Studies Journal, 23(6), 15.

Verma, A., \& Joseph T, T. (2019). The Causal Relationship between the Stock Indices of Western Bloc Countries: A Case on Belgium and France. Ushus Journal of Business Management, 18(3), 25-38. https://doi.org/10.12725/ujbm.48.3

Wikipedia, https://tr.wikipedia.org/wiki/NASDAQ (Erişim Tarihi: 3 Aralık 2018)

Worthington, A. C. ve Higgs, H.(2007), Assessing financial integration in European Union equity markets, 1990-2006: Panel unit root and multivariate cointegration and causality evidence 2007. University of Wollongong, School of Accounting and Finance Working Paper Series No. 07/10, 2007 http://ro.uow.edu.au/commpapers/338

Wu, K., Zhu, J., Xu, M. ve Yang, L. (2020). Can crude oil drive the co-movement in the international stock market? Evidence from partial wavelet coherence analysis. The North American Journal of Economics and Finance, 53, 101194. doi:10.1016/j.najef.2020.101194

Yılancı, V. (2009), Yapısal Kırılmalar Altında Türkiye İçin İşsizlik Histerisinin Sınanması. Doğuş Üniversitesi Dergisi, 10(2), 324-335.

Yıldız A ve Aksoy E. (2013), Morgan Stanley Gelişmekte Olan Borsa Endeksi ile BIST Endeksi Arasındaki Eşbütünleşme İlişkisinin Analiz Edilmesi. Atatürk Üniversitesi İktisadi ve İdari Bilimler Dergisi, 28 (1), 1-23. Retrieved from http://dergipark.gov.tr/atauniiibd/issue/2712/35913

Yılmaz, H. (2018), Türkiye'de Sağlık Harcamalarının Makroekonomik Değişkenler Üzerindeki Etkileri. Aydın: (Yüksek Lisans Tezi), T.C Aydın Adnan Menderes Üniversitesi, SBE, İktisat Anabilimdalı.

Zivot, E. ve Andrews, D. (1992), Further Evidence On The Great Crash, The Oil Price Shock, and The Unit Root Hypothesis. Journal of Business \& Economic Statistics, 10(3), 251-270. 